Gut, 1973, 14, 856-860

\title{
Gastrin in portal and peripheral venous blood after feeding in man
}

\author{
H. DENCKER, R. HÅKANSON, G. LIEDBERG, C. NORRYD, J. OSCARSON, \\ J. F. REHFELD, AND F. STADIL \\ From the Departments of Surgery and Pharmacology, University of Lund, Lund, Sweden, \\ the Department of Clinical Chemistry, Bispebjerg Hospital and Department of Gastroenterology C, \\ Rigshospitalet, Copenhagen, Denmark
}

SUMMARY The concentrations of immunoreactive gastrin in serum from portal and peripheral venous blood were determined in 10 patients with indwelling portal catheters before and after feeding. No significant differences were found between the gastrin concentrations in portal and peripheral serum. Gel filtration studies of serum did not reveal any differences between the gastrin components of portal and peripheral venous serum. Since neither the concentrations of immunoreactive gastrin nor the four gastrin components differed between portal and peripheral serum it is suggested that the liver is without effect on gastrin metabolism.

Portal caval shunting results in gastric hypersecretion of acid in the dog (Lebedinskaja, 1933; Clarke, McKissock, and Cruze, 1959), rat (Fisher and Snyder, 1965), and man (Orloff, Chandler, Alderman, Keiter, and Rosen, 1969). The mechanism is not yet elucidated. Available data indicate that the hypersecretion is mediated by humoral agents. These agents may either be derived from the gastrointestinal tract and escape inactivation by the liver due to the shunting or may be liberated from the liver after it has been deprived of its portal blood supply (Silen, Hein, Albo, and Harper, 1963).

Among other agents, gastrin has been implicated as the factor responsible for the hypersecretion following portal caval shunting (for references, see Thompson, 1969).

The purpose of the present study was to assess whether gastrin is affected by liver passage in man. The concentration and the distribution of components of immunoreactive gastrin in human subjects were measured directly by a radioimmunoassay technique.

\section{Material and Methods}

\section{PATIENTS}

Ten patients, four females and six males, age 51-71 years, were studied. All had primary malignant tumours in the lower gastrointestinal tract with suspected

Received for publication 18 July 1973. metastases in the liver. Portal catheterization was performed in order to permit radiological studies of the hepatic portal system. In no patient was the presence of a liver metastasis detected.

\section{TECHNIQUEFOR PORTAL CATHETERIZATION}

The skin and linea alba was opened under local anaesthesia by a short midline incision between the umbilicus and the xiphisternum. The umbilical vein was identified, opened, and dilated with a bougie until the passage into the left branch of the portal vein was opened. A catheter (infant feeding tube no. 8) was then placed with its tip in the portal vein, secured in place, and the incision closed in layers. The position of the catheter was established by fluoroscopy (Dencker, Göthlin, Meeuwisse, and Tranberg, 1972).

\section{DETERMINATION OF GASTRIC ACID OUTPUT}

The patients were fasted overnight and a doublelumen gastric tube was introduced. The stomach was emptied, and basal gastric secretion was aspirated during one hour. Pentagastrin (Peptavlon) was given subcutaneously in a dose of $6 \mu \mathrm{g} / \mathrm{kg}$ and four further 15-minute samples were collected. The gastric acid output was determined by titration to $\mathrm{pH}$ 7. The results are given as basal acid output (BAO) and peak acid output (PAO, obtained by doubling the acid output during the 30 minutes of maximal secretion) expressed as milliequivalents per hour. 


\section{BLOOD SAMPLING}

Collections were started at 9-10 hours am after fasting the patients overnight. Three blood samples were drawn from the portal and cubital veins at five-minute intervals, after which the patients were given a standard meal consisting of meat balls, potatoes, gravy, and a bottle of beer. After 15, 30, $45,60,90,120,150$, and 180 minutes portal and peripheral samples were collected simultaneously. After separation the serum was lyophilized and kept at $+4^{\circ} \mathrm{C}$ until gastrin analysis.

\section{GEL FILTRATION OF SERUM}

Serum samples, each of $1.5 \mathrm{ml}$, were applied to a Sephadex G-50 superfine column $10 \times 2000 \mathrm{~mm}$ and eluted with $0.1 \mathrm{M}$ sodium phosphate, $\mathrm{pH} 7 \cdot 4$, containing $0.6 \mathrm{mM}$ ethyl-mercuric-thiosalicylate, at a constant flow rate of $5.4 \mathrm{ml}$ per hour at $20^{\circ} \mathrm{C}$. The column was calibrated with ${ }^{125} \mathrm{I}$-albumin, monocomponent porcine proinsulin, human insulin, synthetic human gastrin I, and ${ }^{22} \mathrm{NaCl}$. Each serum sample was mixed with ${ }^{125}$ I-albumin monocomponent insulin and ${ }^{22} \mathrm{NaCl}$ before application to the column, for internal standardization. Fractions of $2.0 \mathrm{ml}$ were collected, counted, and assayed for immunoreactive gastrin and insulin.

\section{RADIOIMMUNOANALYSIS}

Gastrin was measured by radioimmunoassay as previously described (Rehfeld, Stadil, and Rubin, 1972). Synthetic human gastrin was purified and monoiodinated by a modification (Stadil and Rehfeld, 1972) of the chloramine technique, resulting in a labelled gastrin with immunoreactivity indistinguishable from unlabelled synthetic gastrin. The detection limit of the assay was $<0.2 \mathrm{pmol} / \mathrm{l}$ eluate, using the rabbit antiserum 2604-8 with a $\mathrm{K}^{\circ}$ of $2 \times$ $10^{12} 1$ per mole. This antiserum was employed in a final dilution of $1: 180000$. The precision, specificity, and the accuracy of the assay has been evaluated in detail elsewhere (Stadil and Rehfeld, 1973). Immunoreactive insulin was measured by a wickchromatographic assay with a detection limit of 5 pmol per 1. Details on the parameters of the assay have previously been described (Rehfeld and Stadil, 1973a).

\section{Results}

Serum gastrin concentrations were abnormally high in the fasting state in three patients (fig 2). These patients had a low gastric acid secretion with a BAO of $0.06 \pm 0.03$ and a PAO of $4.0 \pm 3.7 \mathrm{~m}$-equiv/ $\mathrm{h}$ (mean $\pm \mathrm{SEM}$ ). Acid secretory studies were obtained from three of the seven patients with normal serum gastrin levels; these had a normal acid output with 2

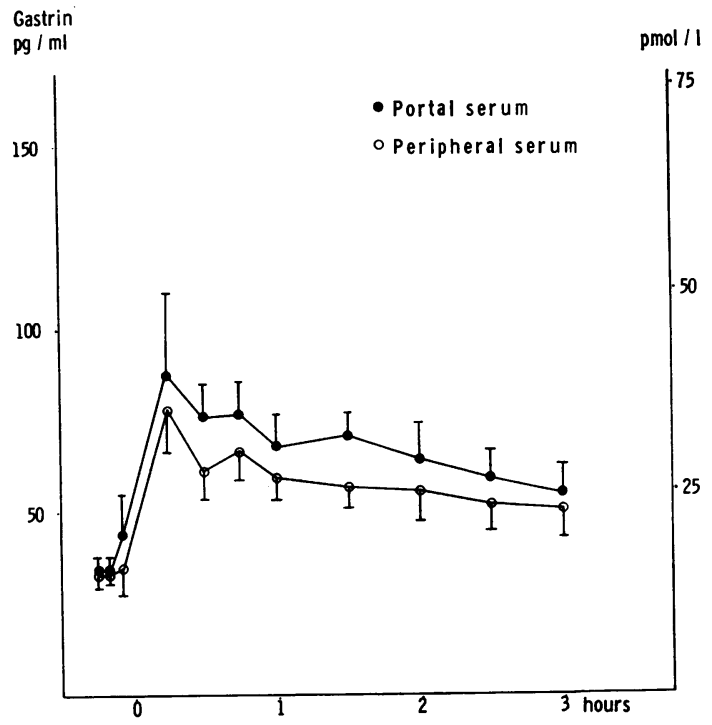

Fig 1 Immunoreactive gastrin concentrations in portal (closed circles) and peripheral (open circles) serum before and after feeding. Mean $\pm S E M, n=7$.

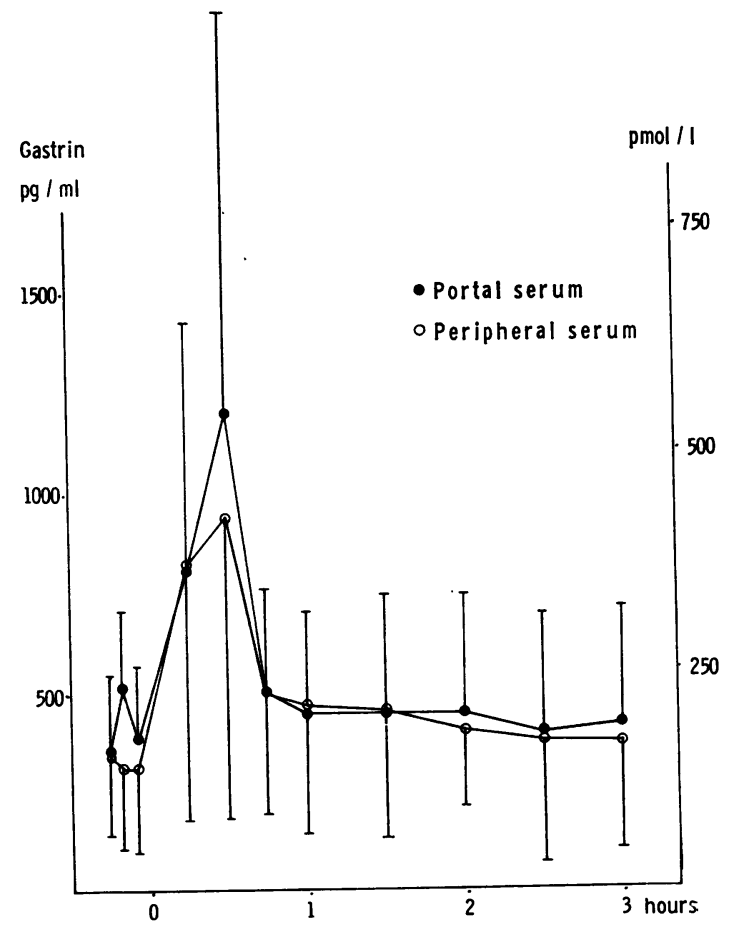

Fig 2 Immunoreactive gastrin concentrations in portal (closed circles) and peripheral (open circles) serum in patients with hypergastrinaemia. Mean $\pm S E M, n=3$. 


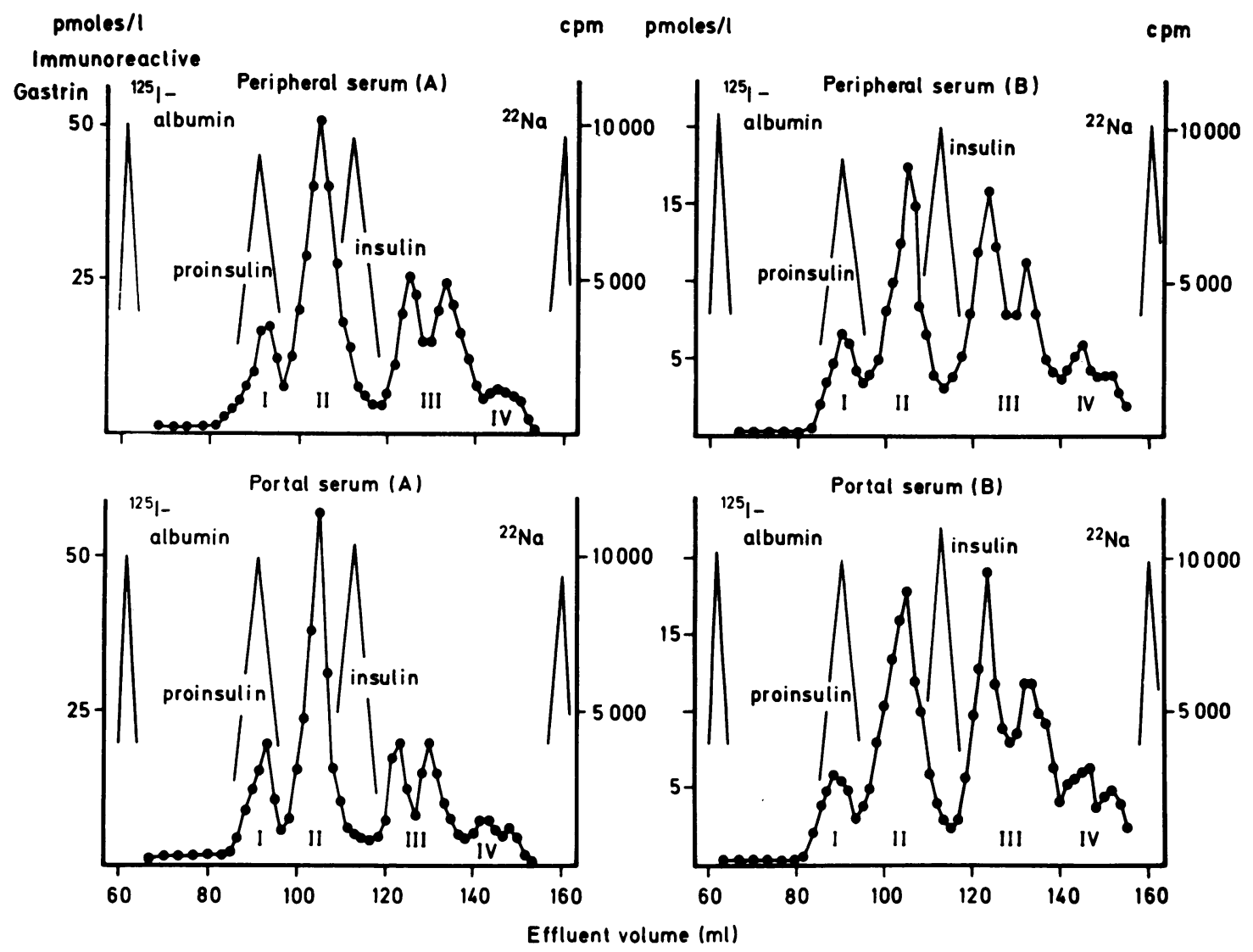

Fig 3 Elution of immunoreactive gastrin ( - O) in serum from two patients, $A$ and $B$ respectively, by gel filtration on Sephadex G-50 superfine columns, $10 \times 2000 \mathrm{~mm}$. The columns were calibrated with ${ }^{125}$ I-albumin, proinsulin, insulin, and ${ }^{22} \mathrm{NaCl}$. Immunoreactive gastrin was distributed in four components, I-IV.

a BAO of $1.1 \pm 0.7$ and a PAO of $20.4 \pm 7.8$ mequiv/h.

Pre- and postprandial concentrations of gastrin in serum from portal and peripheral venous blood in the three hypergastrinaemic and seven normogastrinaemic patients are shown in figures 1 and 2. In neither group were there any differences between the fasting gastrin levels in portal and peripheral serum. Feeding induced a rapid increase in serum gastrin in both portal and peripheral blood with a maximum after 15 to 30 minutes, followed by a gradual decrease. In the hypergastrinaemic group there were no differences between the postprandial serum gastrin concentrations in portal and peripheral blood (fig 2). In the normogastrinaemic patients the serum gastrin levels after feeding were slightly higher in portal than in peripheral blood (fig 1). The differences, however, were small and not statistically significant $(P>0.05$, Student's $t$ test for paired observations). The distribution of gastrin immunoreactivity in different gastrin components separated by gel filtration was found to be similar in portal and peripheral serum (fig 3).

\section{Discussion}

Portal-systemic shunting results in gastric acid hypersecretion, which seems to be due mainly to a marked augmentation of the intestinal phase of acid secretion (Clarke et al, 1959; Hayashi, Rheault, Semb, and Nyhus, 1968; Newman, Reeder, Davidson, Schneider, Miller, and Thompson, 1969; Thompson, 1969; Orloff et al, 1969). Spleno-caval shunting alone, in the dog, also produces hypersecretion, but of a lesser degree than mesentericocaval shunting (Hayashi et al, 1968), indicating that 
a gastric, humoral factor (gastrin) might also participate.

Studies on the effect of the liver on gastrin are somewhat contradictory. Several investigators have reported that gastrin is, at least partially, degraded or inactivated by the liver (Castaneda, Griffen, Nicoloff, Leonard, and Wangensteen, 1960; Kaulbersz and Bilski, 1962; Thompson, Reeder, Davidson, Charters, Brückner, Lemmi, and Miller, 1970; Beger, Kraas, Meves, Witte, Bittner, and von Hardenberg, 1972). On the other hand, Gillespie and Grossman (1962) did not find that portal administration of gastrin diminished the acid secretory response as compared to systemic administration, and McGuigan, Jaffe, Newton (1969) found no differences in portal and systemic radioimmunoassayable endogenous gastrin in dogs. In experiments on dogs, Reeder, Brandt, Watson, Hjelmquist, and Thompson (1972) measured the total mass of endogenous gastrin entering and leaving the liver during basal conditions and after the stimulation of gastrin release by locally administered acetylcholine. They could not find any significant decrease in the amount of immunoassayable gastrin during passage through the liver. The results of the present investigation suggest that endogenous gastrin in man, as measured by radioimmunoassay, is not to any greater extent inactivated by the liver. The slightly lower gastrin levels noticed in peripheral blood are most likely caused by dilution only and are probably not to be considered a result of degradation or inactivation of endogenously released gastrin by the liver.

Even if the liver has little or no effect on synthetic, heptadecapeptide gastrin, it is evident, that pentagastrin, which contains the biologically active C-terminal tetrapeptide of gastrin, is rapidly destroyed by the liver (Thompson et al, 1969; Temperley, Stagg, and Wyllie, 1971). This suggests that the liver might handle peptides with gastrin-like activity differently dependent upon their size. Gastrin in human serum is heterogenous. There appear to be at least four components of different molecular size (Rehfeld and Stadil, 1973b). By ion exchange chromatography it has been demonstrated that component $I$ is unpaired, while components II-IV circulate as pairs. Each pair probably consists of one sulphated and one unsulphated isopeptide as is known for the heptadecapeptide gastrins (Rehfeld, Stadil, and Vikelsoe, 1973). The present study did not disclose any significant alterations in the pattern of gastrin components attributable to hepatic transit.

In conclusion, passage through the liver has not been found to affect the concentration or molecular size of immunoreactive gastrin in serum. These findings, however, do not disprove the hypothesis $2^{*}$ that gastrin may be one factor responsible for the hypersecretion of acid after portal-caval shunting. The possibility still remains that the shunting procedure as such augments the release of gastrin from its cellular stores in the gastrointestinal mucosa.

This study was supported by grants from the Swedish Medical Research Council (K73-14X-4144-01) and the Danish Medical Research Council (512-1665).

\section{References}

Beger, H. G., Kraas, E., Meves, M., Witte, C., Bittner, R., and von Hardenberg, C. (1972). Ueber den Einfluss der Leber auf die Wirkung von Gastrin: ein Beitrag zur Genese des Ulcus pepticum. Langenbecks Arch. klin. Chir., Suppl., 215-218.

Castaneda, A., Griffen, W. O., Jr., Nicoloff, D., Leonard, A. S., and Wangensteen, O. H. (1960). Antral hyperfunction following portacaval shunt. Surg. Forum, 11, 349-351.

Clarke, J. S., McKissock, P. K., and Cruze, K. (1959). Studies on the site of origin of the agent causing hypersecretion in dogs with portacaval shunt. Surgery, 46, 48-54.

Dencker, H., Göthlin, J., Meeuwisse, G., and Tranberg, K. G. (1972). Human intestinal absorption of glucose measured by portal catheterization. Scand. J. Gastroent., 7, 451-453.

Fischer, J. E., and Snyder,S. H. (1965). Histamine synthesis and gastric secretion after portacaval shunt. Science, 150, 1034-1035.

Gillespie, I. E., and Grossman, M. I. (1962). Gastric secretion of acid in response to portal and systemic venous injection of gastrin. Gastroenterology, 43, 189-192.

Hayashi, K., Rheault, M. J., Semb, L. S., and Nyhus, L. M. (1968). The effect of splenocaval shunt on gastric secretion and liver function as compared with other shunting procedures in the dog. Surgery, 64, 1084-1091.

Kaulbersz, J., and Bilski, R. (1963). Gastric secretion after introduction of gastrin into the portal vein. In Proceedings of the IInd World Congress of Gastroenterology, Munich 1962, vol. 2, pp. 75-79.

Lebedinskaja, S. I. (1933). Ueber die Magensekretion bei Eckschen Fistelhunden. Z. ges. exp. Med., 88, 264-270.

McGuigan, J. E., Jaffe, B. M., and Newton, W. T. (1969). Immunochemical measurement of endogenous gastrin release and circulation. Gastroenterology, 56, 1181.

Newman, P. H., Reeder, D. D., Davidson, W. D., Schneider, E., Miller, J. H., and Thompson, J. C. (1969). Acid secretion following portacaval shunting. Arch. Surg., 99, 369-375.

Orloff, M. J., Chandler, J. G., Alderman, S. J., Keiter, J. E., and Rosen, H. (1969). Gastric secretion and peptic ulcer following portacaval shunt in man. Ann. Surg., 170, 515-524.

Reeder, D. D., Brandt, E. N., Jr., Watson, L. C., Hjelmquist, U. B. E., and Thompson, J. C. (1972). Pre- and posthepatic measurement of mass of endogenous gastrin. Surgery, 72, 34-41.

Rehfeld, J. F., Stadil, F., and Rubin, B. (1972). Production and evaluation of antibodies for the radioimmunoassay of gastrin. Scand. J. clin. Lab. Invest., 30, 221-232.

Rehfeld, J. F., and Stadil, F. (1973a). The effect of gastrin on basaland glucose-stimulated insulin secretion in man. J. clin. Invest., in press.

Rehfeld, J. F., and Stadil, F. (1973b). Gel filtration studies on immunoreactive gastrin in serum from Zollinger-Ellison patients. Gut, 14, 369-373.

Rehfeld, J. F., Stadil, F., and Vikelsoe, J. (1973). Immunoreactive gastrin components in human serum: further characterization by gel filtration and cellulosic ion exchange chromatography. Submitted for publication in Biochim. biophys. Acta. (Amst.).

Silen, W., Hein, M. F., Albo, R. J., and Harper, H. A. (1963). Influence of liver upon canine gastric secretion. Surgery, 54, 29-35.

Stadil, F., and Rehfeld, J. F. (1972). Preparation of ${ }^{126} \mathrm{I}$-labelled synthetic human gastrin I for radioimmunoanalysis. Scand. J. clin. Lab. Invest., 30, 361-368.

Stadil, F., and Rehfeld, J. F. (1973). Determination of gastrin in serum: an evaluation of the reliability of a radioimmunoassay. Scand. J. Gastroent., 8, 101-112. 
Temperley, J. M., Stagg, B. H., and Wyllie, J. H. (1971). Disappearance of gastrin and pentagastrin in the portal circulation. Gut, 12, 372-376.

Thompson, J. C. (1969). Alterations in gastric secretion after portacaval shunting. Amer. J. Surg., 117, 854-865.
Thompson, J. C. Reeder, D. D., Davidson, W. D., Charters, A. C. Brü:kner, W. L., Lemmi, C. A. E., and Miller, J. H. (1970). Effect of hepatic transit of gastrin, pentagastrin and histamine measured by gastric secretion and by assay of hepatic vein blood. Ann. Surg., 170, 493-503. 